\title{
Cardiac-specific methylation patterns of circulating DNA for identification of cardiomyocyte death
}

Qin Liu', Jian Ma², Hua Deng ${ }^{2}$, Shu-Jun Huang ${ }^{2}$, Jiao Rao ${ }^{1}$, Wei-Bin $\mathrm{Xu}^{1}$, Jing-Si Huang ${ }^{1}$, Shan-Quan Sun ${ }^{1 *}$ and Liang Zhang ${ }^{2^{*}}$ (D)

\begin{abstract}
Background: Correct detection of human cardiomyocyte death is essential for definitive diagnosis and appropriate management of cardiovascular diseases. Although current strategies have proven utility in clinical cardiology, they have some limitations. Our aim was to develop a new approach to monitor myocardial death using methylation patterns of circulating cell-free DNA (cf-DNA).

Methods: We first examined the methylation status of FAM101A in heart tissue and blood of individual donors using quantitative methylation-sensitive PCR (qMS-PCR). The concentrations and kinetics of cardiac cf-DNA in plasma from five congenital heart disease (CHD) children before and after they underwent cardiac surgery at serial time points were then investigated.

Results: We identified demethylated FAM101A specifically present in heart tissue. Importantly, our time course experiments demonstrated that the plasma cardiac cf-DNA level increased quickly during the early post-cardiac surgery phase, peaking at 4-6h, decreased progressively ( $24 \mathrm{~h}$ ) and returned to baseline (72 h). Moreover, cardiac cf-DNA concentrations pre- and post-operation were closely correlated with plasma troponin levels.

Conclusions: We proposed a novel strategy for the correct detection of cardiomyocyte death, based on analysis of plasma cf-DNA carrying the cardiac-specific methylation signature. Our pilot study may lead to new tests for human cardiac pathologies.
\end{abstract}

Keywords: Cardiomyocyte death, Circulating cell-free DNA, Methylation biomarker, FAM101A, qMS-PCR

\section{Background}

Cardiovascular diseases are the leading causes of death worldwide [1]. Accurate detection of human cardiomyocyte death is crucial for implementing early diagnosis, effective intervention of the disorders. Currently, cardiac-specific troponins (cTns) are widely accepted markers of acute myocardial infarction in clinical

\footnotetext{
*Correspondence: brightsun999@163.com; zhangliang1999@tsinghua.org.cn 'Cardiac center, Guangdong Women and Children Hospital, Guangzhou 511400, China

${ }^{2}$ Translational medicine center, Guangdong Women and Children Hospital, Guangzhou 511400, China
}

practice. However, these biomarkers also have some limitations. Release of troponins into the blood may not necessarily reflect the cardiomyocyte death because cardiac troponins could be released by ischemia alone [2]. For example, healthy individuals after intensive physical exercises, or critically ill patients in intensive care unit may release troponins into circulation leading to elevated troponin levels [3-5]. To date, we do not know whether elevated troponin levels represent cardiomyocyte death, or just reversible cardiomyocyte injury [6, 7]. Moreover, kidney dysfunction can markedly affect troponin clearance [8], which may complicate the explanation of

(c) The Author(s). 2020 Open Access This article is licensed under a Creative Commons Attribution 4.0 International License, which permits use, sharing, adaptation, distribution and reproduction in any medium or format, as long as you give appropriate credit to the original author(s) and the source, provide a link to the Creative Commons licence, and indicate if changes were made. The images or other third party material in this article are included in the article's Creative Commons licence, unless indicated otherwise in a credit line to the material. If material is not included in the article's Creative Commons licence and your intended use is not permitted by statutory regulation or exceeds the permitted use, you will need to obtain permission directly from the copyright holder. To view a copy of this licence, visit http://creativecommons.org/licenses/by/4.0/. The Creative Commons Public Domain Dedication waiver (http://creativecommons.org/publicdomain/zero/1.0/) applies to the data made available in this article, unless otherwise stated in a credit line to the data. 
elevated troponin levels in subjects suffered from renal failure. In fact, one of the most important comorbidities in heart failure patients is renal insufficiency $[9,10]$. Therefore, development of a new and reliable method is needed to monitor and quantify myocardial death in clinical settings.

Circulating cell-free DNA (cf-DNA), nucleosome-size fragments of genomic DNA in blood, originates from dying cells. In recent years, increased levels of cf-DNA have been found in pathological conditions and clinical diseases such as embryonic chromosomal abnormality [11], tumor prognosis or cancer metastasis [12, 13], inflammation [14], and transplant rejection [15]. Plasma cf-DNA in general may be elevated during tissue injury including cardiomyocyte death and may also be a prognostic indicator of cardiac health [16-20]. However, this phenomenon is not cardiac specific.

Each cell type has a unique DNA methylation pattern, and some tissue-specific DNA methylation biomarkers have been identified [21]. With the advances in methylation analysis, combination of cf-DNA and methylation patterns can trace the tissue origin in circulation [22-24]. More recently, Zemmour et al. found demethylated FAM101A in heart tissues, in contrast to methylated FAM101A in other human tissues including blood. Thus, the unmethylated FAM101A present in a given pool of circulating cf-DNA may be a specific indicator for cardiomyocyte death [25]. Further, they identified high levels of cardiomyocyte cf-DNA in plasma from patients with acute myocardial infarction using droplet digital PCR (ddPCR). In the present study, we used qMS-PCR to determine FAM101A cf-DNA in plasma from five children with congenital heart disease (CHD) undergoing cardiac surgery and concluded that measurement of cardiac cf-DNA levels can indeed detect cardiomyocyte death.

\section{Methods}

\section{Patients and specimens}

The study protocol was approved by the Institutional Review Board of Guangdong Women and Children
Hospital and conducted in accordance with the Declaration of Helsinki. Written informed consent was obtained from the individual donors and guardians of all children. We recruited five infants ( 4 boys and 1 girl, aged 4 days to 2 years) diagnosed with CHD including complete transposition of the great arteries, coarctation of the aorta, coarctation of the aorta with ventricular septal defect into our study. Clinical characteristics for each patient are summarized in Table 1 . The main clinical manifestations were cyanosis and dyspnea. After cardiac surgery, all the young patients recovered well and were discharged without complications.

Since atrial appendage is a remnant of the primitive atrium and it does not affect the heart functions, atrial appendage tissue $(5 \times 5 \mathrm{~mm})$ was taken from a patient with atrial fibrillation during surgery to assess the specificity of the cardiac methylation biomarker. Peripheral blood samples were collected from CHD patients before and after they underwent cardiac surgery at serial time points in Cell-Free DNA Storage Tube containing EDTA (Genphar Company, Guangzhou, China) for methylation analysis of FAM101A cf-DNA. In addition, the same samples were subjected to measurement of serum levels of cTn-I.

\section{DNA extraction}

Genomic DNA from heart tissue was isolated using the TIANamp Genomic DNA Extraction Kit according to the manufacturer's protocol (Tiangen Biotech, Beijing). Whole blood was centrifuged quickly at $1350 \pm 150 \mathrm{RCF}$ for $10 \mathrm{~min}$ at room temperature. Plasma was carefully transferred to a new tube and then stored at $-20^{\circ} \mathrm{C}$ until DNA extraction. Cell-free DNA was isolated from plasma using the Nucleic Acid Purification/Magnetic Beads Kit (GENESHINE, Shanghai, China) following the manufacturer's recommendations. DNA concentrations were quantitated using the Qubit ${ }^{\circ}$ dsDNA HS Assay Kit (Thermo Fisher Scientific).

Table 1 Clinical information for each patient

\begin{tabular}{|c|c|c|c|c|c|c|c|}
\hline Case & Gender & Age & $\begin{array}{l}\text { Weight } \\
(\mathrm{kg})\end{array}$ & $\begin{array}{l}\text { Length } \\
(\mathrm{cm})\end{array}$ & Diagnosis & Clinical symptom & Types of cardiac surgery \\
\hline 1 & M & $11 d$ & 3.8 & 55 & $\begin{array}{l}\text { CoA with aortic arch hypoplasia, } \\
\text { PFO, PH }\end{array}$ & Dyspnea & Coarctation repair \\
\hline 2 & M & $2 m$ & 4 & 56 & $\begin{array}{l}\text { CoA with aortic arch hypoplasia, } \\
\text { PFO, PH, VSD }\end{array}$ & Dyspnea, cyanosis & Aortic arch repair, VSD repair \\
\hline 3 & M & $2 y$ & 12.2 & 81 & $\begin{array}{l}\text { CoA with aortic arch hypoplasia, } \\
\text { VSD (muscular) }\end{array}$ & $\begin{array}{l}\text { Dyspnea after } \\
\text { exercise }\end{array}$ & Aortic arch repair, VSD repair \\
\hline 4 & M & $4 d$ & 3.3 & 50 & TGA/IVS, PDA, PFO & $\begin{array}{l}\text { Dyspnea, cyanosis, } \\
\text { arrhythmia }\end{array}$ & ASO, PDA ligation \\
\hline 5 & $\mathrm{~F}$ & $13 d$ & 3.7 & 47 & TGA/IVS, ASD, PDA, PFO, Ti, PH & Dyspnea, cyanosis & $\begin{array}{l}\text { ASO, PDA ligation, ASD repair, unplanned } \\
\text { sternum left open }\end{array}$ \\
\hline
\end{tabular}


Quantitative methylation-sensitive PCR (qMS-PCR)

The isolated cf-DNA was treated with bisulfite using the GS DNA Methylation Kit (GENESHINE, Shanghai, China). The bisulfite-converted DNA was immediately subjected to a qMS-PCR assay. The cycling conditions were $94^{\circ} \mathrm{C}$ for $10 \mathrm{~min}$, followed by 50 cycles of $93^{\circ} \mathrm{C}$ for $30 \mathrm{~s}, 56^{\circ} \mathrm{C}$ for 1 min and $65^{\circ} \mathrm{C}$ for $30 \mathrm{~s}$, ended by $40^{\circ} \mathrm{C}$ for $30 \mathrm{~s}$. All analyses were performed on an ABI 7500 Fast Real-Time PCR system (Applied Biosystems) and tests for each sample were performed in triplicates. The house keeping gene beta actin (ACTB) was measured as an internal control. The cycle threshold $(\mathrm{Ct})$ value for ACTB less than 32 ensured good sample quality and indicated the validity of the testing. We measured the $\mathrm{Ct}$ values for FAM101A and ACTB in each sample and the DNA methylation level was calculated based on the differences between the two Ct values $(\Delta \mathrm{Ct}=$ $\left.\mathrm{Ct}^{\text {FAM101A }}-\mathrm{Ct}^{\mathrm{ACTB}}\right)$. To optimize the performance of the assay, a $\Delta$ Ct value $<9$ for positive testing was established in our pilot experiments. We designed forward primer to cover 3 CpG sites (CpG 1-3) in the cluster, probe for CpG 5, 6 and reverse primer located downstream of the locus using Primer premier 5.0 (Fig. 1). The length of the amplified product was $144 \mathrm{bp}$. The following primer and probe sequences were used for qMS-PCR:

FAM101A-F:5' - ATGATTGATAATAATGTATGGTG 3' (CpGs in italics).

FAM101A-R:5' - CCTCCACAAAATTTACCT -3'.

FAM101A-P:5'FAM- TCAACTTCCATCTACAATTCCCA -3' MGB (CpGs in italics).

ACTB-F: 5'-TGGTGATGGAGGAGGTTTAGTAAGT-3'. ACTB-R: 5'-ACCAATAAAACCTACTCCTCCCTTAA-3'. ACTB-P: 5'HEX- ACCACCACCCAACACACAATAA CAAA CACA-3'BHQ1.

\section{Measurement of cTn-I}

Quantitative measurement of cTn-I in serum was conducted using a commercially available fluorescence immunoassay (M101-091011", MicroPointBio, Shenzhen, China) according to the manufacturer's recommendations.
The concentration of each analyte in the specimen is directly proportional to the fluorescence intensity.

\section{Results}

Identification of unmethylated FAM101A in heart tissue

To assess the specificity and utility of the cardiac methylation biomarker in our qMS-PCR assays, we analyzed the methylation status of FAM101A in known positive (heart tissue with demethylated FAM101A) and negative (blood with methylated FAM101A) samples based on a prior study. As expected, strong amplification signal was detected in heart tissue, whereas a negative result was found in blood (Fig. 2a-b), indicating the validity of the new approach.

\section{Methylated FAM101A DNA in the circulation confirmed by sanger sequencing}

To ascertain the methylation status of FAM101A in heart tissue and blood, we designed another pair of primers (FAM101A-F: ATGGATAAGGAAATTAAG ATAG, FAM101A-R: AAATACAAATCCCACAAATA $\mathrm{AA})$ to recognize the regions outside the $\mathrm{CpG}$ sites of FAM101A promoter in a regular PCR assay. The resulting PCR products generated from both blood and heart tissue were subjected to Sanger sequencing. Sequencing chromatograms exhibited homozygous base $(C)$ at each targeted CpG site in blood (Fig. 3). However, heterozygous bases $(\mathrm{T} / \mathrm{C})$ at all six $\mathrm{CpG}$ sites were present in heart tissue. This could be ascribed to the fact that heart tissue contains non-cardiac tissues/cells such as vascular and connective tissues. The difference in DNA sequence of FAM101A promoter between the two samples was reliant on the methylation status at the targeted $\mathrm{CpG}$ sites.

\section{Identification of cardiomyocyte death in cf-DNA from patients after cardiac surgery}

Further, we tested whether the new method could be useful in identifying cardiomyocyte death in circulating cf-DNA. To this end, we investigated the plasma levels of cf-DNA in CHD children before and after cardiac

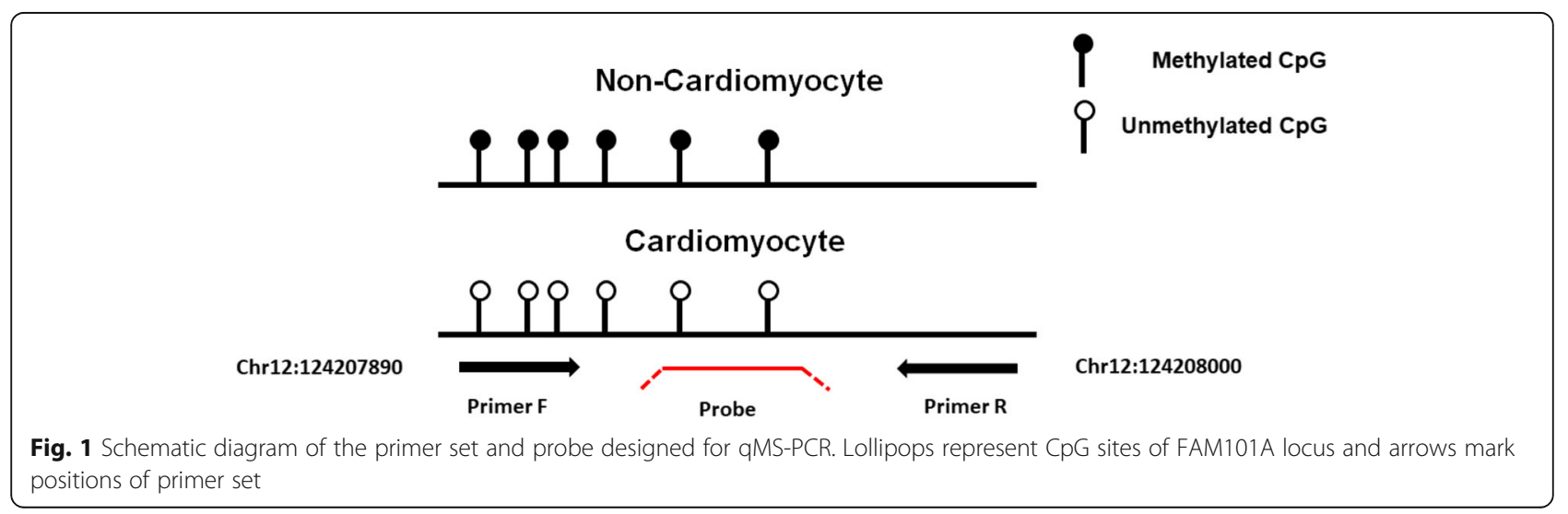



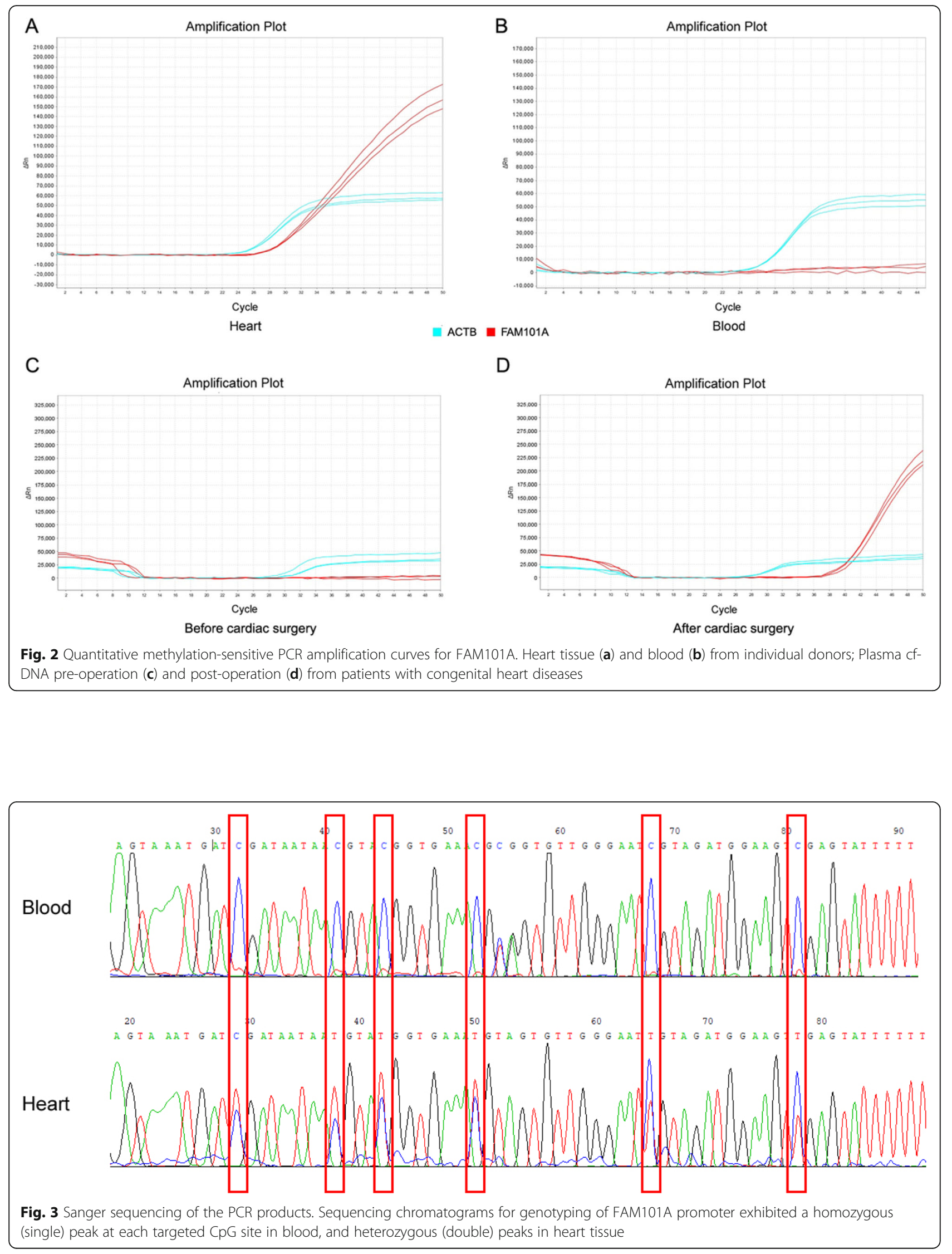
operation. Samples with a $\Delta_{\mathrm{Ct}}$ value $\left(\mathrm{Ct}^{\mathrm{FAM} 101 \mathrm{~A}}\right.$ $\left.\mathrm{Ct}^{\mathrm{ACTB}}\right)<9$ were considered to represent a positive test result. Overall, similar findings were observed among the five subjects and determining the cardiac cf-DNA levels can indeed detect cardiomyocyte damage (Fig. 2cd). To further examine the temporal course of cardiac cf-DNA, we analyzed the concentrations of plasma demethylated FAM101A before and after cardiac surgery at serial time points. As shown in Fig. 4, we identified the low levels of cardiac cf-DNA pre-operation, a large increase at $4-6 \mathrm{~h}$ post-cardiac surgery, followed by a progressive decrease to baseline $(24 \mathrm{~h}-72 \mathrm{~h})$.

\section{Correlation of plasma cf-DNA with cardiac troponin levels}

To compare the new molecular signature with classic cardiac biomarker, cTn-I was also examined with a fluorescence immunoassay. Both cardiac cf-DNA and troponin levels were elevated in all instances of post-operation, and then decayed to a low level. Overall, cTn-I levels correlated well with cardiac cf-DNA concentrations at serial time points (Table 2 and Fig. 4). The findings demonstrated the suitability and robustness of the novel biomarker for non-invasive monitoring cardiomyocyte death.

\section{Discussion}

Plasma cf-DNA is derived from dying cells and many human cells can release DNA into the blood. Thus, circulating cf-DNA is a composite of multiple heterogeneous cell origins [26]. DNA methylation is an ideal indicator for source tissue of plasma cf-DNA because it reflects cell identity. A prior work revealed that demethylated
FAM101A was found only in heart tissues using ddPCR [25]. Since ddPCR is quite expensive and complicated, whereas $\mathrm{qPCR}$ is a routine technique in molecular labs, we thus established a qMS-PCR assay to trace cardiomyocyte death during the perioperative period via methylation analysis of FAM101A in plasma cf-DNA. Using ACTB gene as an internal reference, we can perform relative quantitation of FAM101A methylation in a simple and easy way. Elevated cardiac cf-DNA was determined in blood from patients after cardiac surgery, indicating the ability of the new strategy that allows inference of cellular origins of circulating cf-DNA in a specific manner. Our study may expand the clinical applications of the cardiacspecific methylation patterns of circulating cf-DNA. The new biomarker should find utility in diagnosis and monitoring of cardiac pathologies.

In a previous study, Zemmour et al. have comprehensively checked the methylation status of FAM101A in 23 other human cell types/tissues including hepatocytes, B cells, breast luminal cells, breast myoepithelial cells, fibroblasts, neutrophils, monocytes, keratinocytes, adipose tissue, muscle, aorta, adrenal gland, pancreas, liver, lung, small intestine, spleen, esophagus, colon, thymus, ovary, hippocampus and stomach [23]. They found that heart tissues (right atrium and left/right ventricle) had dramatically higher levels of demethylated FAM101A compared with 23 other human tissues, indicating an excellent cardiac specificity of FAM101A methylation in the tissue panel examined. Since they have already done that work, we used heart tissue as a positive sample with high levels of cardiac specific DNA and blood as a negative control

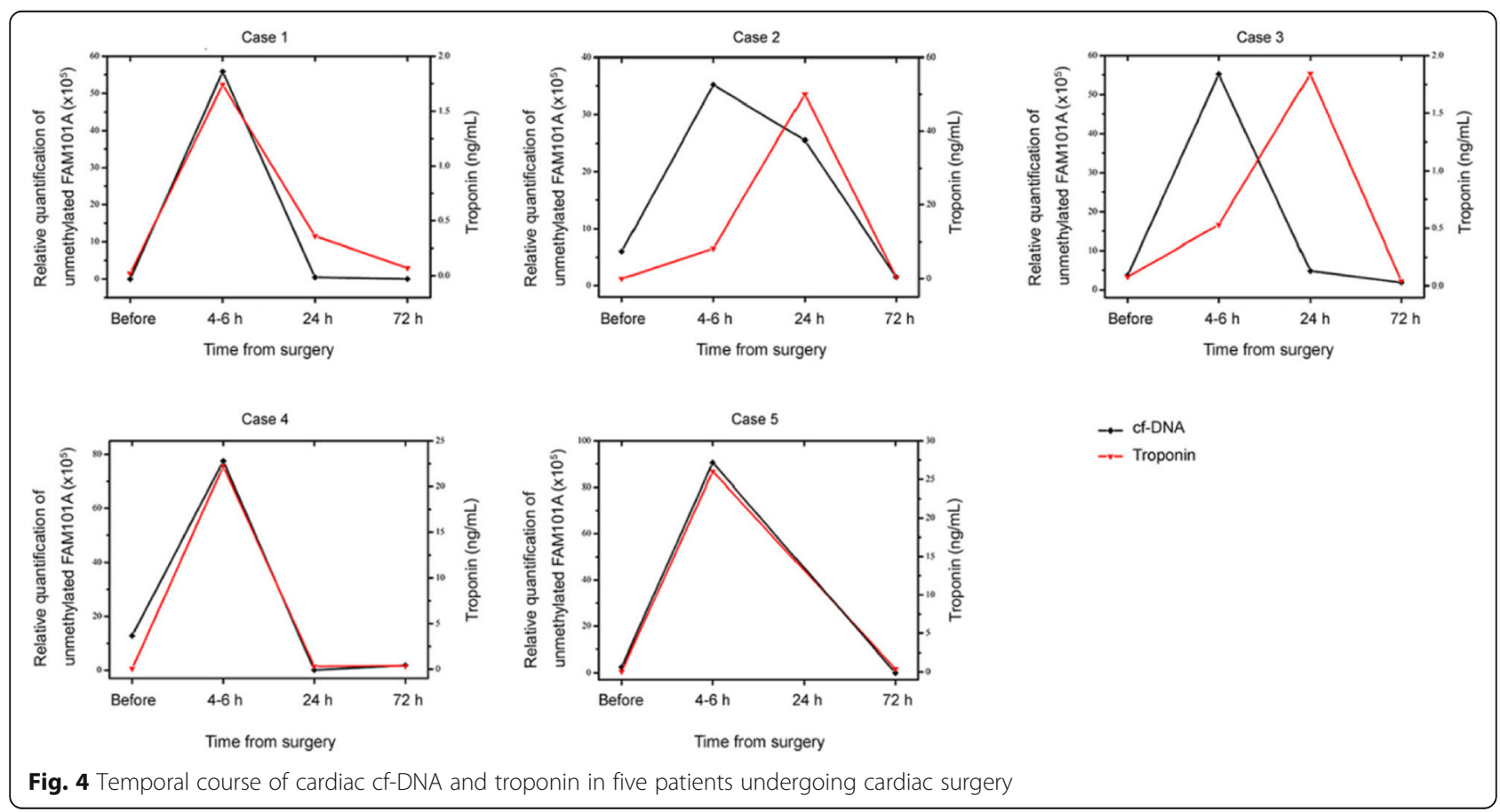


Table 2 Comparison of plasma cardiac cf-DNA and troponin levels in patients before/after surgery

\begin{tabular}{|c|c|c|c|c|c|}
\hline Case & Gender & Diagnosis & Time points & Demethylated FAM101A & cTn-I \\
\hline \multirow[t]{4}{*}{1} & Male & $\mathrm{CHD}$ & Before cardiac surgery & - & - \\
\hline & & & 4-6 h after cardiac surgery & + & + \\
\hline & & & $24 \mathrm{~h}$ after cardiac surgery & - & - \\
\hline & & & $72 \mathrm{~h}$ after cardiac surgery & - & - \\
\hline \multirow[t]{4}{*}{2} & Male & $\mathrm{CHD}$ & Before cardiac surgery & - & - \\
\hline & & & 4-6 h after cardiac surgery & + & + \\
\hline & & & $24 \mathrm{~h}$ after cardiac surgery & + & + \\
\hline & & & $72 \mathrm{~h}$ after cardiac surgery & - & - \\
\hline \multirow[t]{4}{*}{3} & Male & $\mathrm{CHD}$ & Before cardiac surgery & - & - \\
\hline & & & 4-6 h after cardiac surgery & + & + \\
\hline & & & $24 \mathrm{~h}$ after cardiac surgery & - & + \\
\hline & & & $72 \mathrm{~h}$ after cardiac surgery & - & - \\
\hline \multirow[t]{4}{*}{4} & Male & $\mathrm{CHD}$ & Before cardiac surgery & - & - \\
\hline & & & 4-6 h after cardiac surgery & + & + \\
\hline & & & $24 \mathrm{~h}$ after cardiac surgery & - & - \\
\hline & & & $72 \mathrm{~h}$ after cardiac surgery & - & - \\
\hline \multirow[t]{3}{*}{5} & Female & $\mathrm{CHD}$ & Before cardiac surgery & - & - \\
\hline & & & 4-6 h after cardiac surgery & + & + \\
\hline & & & $72 \mathrm{~h}$ after cardiac surgery & - & - \\
\hline
\end{tabular}

CHD Congenital heart disease, $C T n-I$ Cardiac troponin-I

without cardiac cf-DNA to confirm the validity and specificity of the new approach.

Because heart tissue contains non-cardiac components such as blood vessels and connective tissues, even blood cells, during a biopsy procedure, thus the heterozygous bases $(\mathrm{T} / \mathrm{C})$ at each targeted $\mathrm{CpG}$ site were observed in heart by Sanger sequencing. From Fig. 3, only methylated FAM1010A molecules corresponding to the homozygous base $(\mathrm{C})$ at $\mathrm{CpG}$ sites was present in blood from a healthy donor. That is critically important in this testing system.

It is not strange for the great individual differences about the cTn-I and cardiac cf-DNA levels among five subjects. Compared with myocardial infarction and ischemic cardiomyopathy, cardiac surgery should be a bigger strike or stress for heart tissue and likely causes the levels of cTn-I and cardiac cf-DNA to soar. In addition, different types of cardiac surgery for various congenital heart diseases may result in distinct heart damage. In fact, great individual differences in cTn-I $(2-10 \mathrm{ng} / \mathrm{mL})$ and cardiac cf-DNA (120-10,000 copies/mL) levels were also found in patients with acute ST-elevation myocardial infarction after primary percutaneous coronary intervention in a recent study [23].

Moreover, we also examined the time course of plasma cf-DNA pre- and post-operation. We identified a large increase of cardiac cf-DNA at 4-6 h after cardiac surgery and decreased progressively ( 24 and $72 \mathrm{~h}$ ) in all five patients. More importantly, we found that the overall kinetics of cardiac cf-DNA were closely correlated with that of cTn-1. For case 2 and case 3, there is a clear shift in the curves for plasma cf-DNA vs. troponin, whereas in all the others the curves are well aligned. The discordant curves may reflect differences in the release and/or clearance rates of cf-DNA and troponin. The observations appear to support the concept that the half-life of circulating cf-DNA is thought to be short, and they are quickly removed by the liver [27]. Plasma cf-DNA may possess a faster response to cardiomyocyte death compared with troponin. Take case 3 for example, it showed high level of demethylated FAM101A and still low level of troponin at 4-6h after cardiac surgery. Elevation in cf-DNA preceded increase in troponin levels, which actually underscores the clinical value of cf-DNA for monitoring the onset and progression of cardiomyocyte death, potentially complementing currently available markers.

This study has some limitations. First, the main issue of the new method is the turnaround time due to the timesensitivity of diagnostics in cardiology. Our sample-toanswer turnaround time was approximately $8 \mathrm{~h}$. Further experiments are required to optimize the procedures. Second, the sample size is small. However, despite the small number of cases studied, plasma cardiac cf-DNA analyses could accurately discriminate the presence or absence of cardiomyocyte death. Other limitations include unequal 
gender balance (only one female patient, four male cases), and the young ages of the individuals $(<2$ years $)$ so that we cannot assess the performance of cardiac cf-DNA in older subjects. In addition, a potential shortcoming is the rather narrow evaluation under cardiac surgery as opposed to other conditions, which are more responsible for myocardial cell death in the population, e.g. myocardial infarction. Further testing of the cardiac-specific methylation marker in clinical settings is warranted.

\section{Conclusions}

In summary, we developed a novel method to accurately detect cardiomyocyte death in plasma cf-DNA by analyzing the methylation status of FAM101A with qMSPCR. Our study adds new insights into this field, and may have a wider application in myocardial pathologies.

\section{Abbreviations}

cf-DNA: Cell-free DNA; cTns: Cardiac-specific troponins; CHD: Congenital heart disease; qMS-PCR: Quantitative methylation-sensitive PCR

\section{Acknowledgements}

Not applicable.

\section{Authors' contributions}

QL, SQS and LZ designed the study and interpreted the data. HD was a major contributor in writing the manuscript. JM and SJH performed qMSPCR assays. JR, WBX and JSH collected the clinical samples and conducted the measurement of CTn-I. All authors have agreed to authorship and order of authorship for this manuscript and all authors read and approved the final manuscript.

\section{Funding}

This research did not receive any specific grant from funding agencies in the public, commercial, or not-for-profit sectors.

\section{Availability of data and materials}

The data set used and/or analyzed during the current study is available from the corresponding author on reasonable request

\section{Ethics approval and consent to participate}

The study protocol was approved by the Institutional Review Board of Guangdong Women and Children Hospital (Reference number: LXSC201903020003) and conducted in accordance with the Declaration of Helsinki. Consent to participate was obtained from parents of the minors included in this study.

\section{Consent for publication}

Not applicable.

\section{Competing interests}

The authors declare that they have no competing interests.

Received: 15 November 2019 Accepted: 15 June 2020

Published online: 29 June 2020

\section{References}

1. Roth GA, Huffman MD, Moran AE, Feigin V, Mensah GA, Naghavi M, Murray CJ. Global and regional patterns in cardiovascular mortality from 1990 to 2013. Circulation. 2015;132(17):1667-78.

2. Hickman PE, Potter JM, Aroney C, Koerbin G, Southcott E, Wu AH, Roberts MS. Cardiac troponin may be released by ischemia alone, without necrosis. Clin Chim Acta. 2010;411(5-6):318-23.

3. Michielsen EC, Wodzig WK, Van Dieijen-Visser MP. Cardiac troponin T release after prolonged strenuous exercise. Sports Med. 2008;38(5):425-35.
4. Roca E, Nescolarde L, Lupon J, Barallat J, Januzzi JL, Liu P, Cruz Pastor M, Bayes-Genis A. The dynamics of cardiovascular biomarkers in non-elite Marathon runners. J Cardiovasc Transl Res. 2017;10(2):206-8.

5. Shave R, Baggish A, George K, Wood M, Scharhag J, Whyte G, Gaze D, Thompson PD. Exercise-induced cardiac troponin elevation: evidence, mechanisms, and implications. J Am Coll Cardiol. 2010;56(3):169-76.

6. Landesberg G, Jaffe AS. 'Paradox' of troponin elevations after non-cardiac surgery. Br J Anaesth. 2015;114(6):863-5.

7. Alcalai R, Planer D, Culhaoglu A, Osman A, Pollak A, Lotan C. Acute coronary syndrome vs nonspecific troponin elevation: clinical predictors and survival analysis. Arch Intern Med. 2007;167(3):276-81.

8. Friden V, Starnberg K, Muslimovic A, Ricksten SE, Bjurman C, Forsgard N, Wickman A, Hammarsten O. Clearance of cardiac troponin T with and without kidney function. Clin Biochem. 2017;50(9):468-74.

9. van Deursen VM, Urso R, Laroche C, Damman K, Dahlstrom U, Tavazzi L, Maggioni AP, Voors AA. Co-morbidities in patients with heart failure: an analysis of the European heart failure pilot survey. Eur J Heart Fail. 2014 16(1):103-11.

10. Lofman I, Szummer K, Hagerman I, Dahlstrom U, Lund LH, Jernberg T. Prevalence and prognostic impact of kidney disease on heart failure patients. Open Heart. 2016:3(1):e000324.

11. Cuckle H, Benn P, Pergament E. Maternal cfDNA screening for Down syndrome--a cost sensitivity analysis. Prenat Diagn. 2013;33(7):636-42.

12. Schwarzenbach $H$, Hoon DS, Pantel K. Cell-free nucleic acids as biomarkers in cancer patients. Nat Rev Cancer. 2011;11(6):426-37.

13. Chen Z, Fadiel A, Naftolin F, Eichenbaum KD, Xia Y. Circulation DNA biological implications for cancer metastasis and immunology. Med Hypotheses. 2005;65(5):956-61.

14. Jylhava J, Nevalainen T, Marttila S, Jylha M, Hervonen A, Hurme M. Characterization of the role of distinct plasma cell-free DNA species in ageassociated inflammation and frailty. Aging Cell. 2013;12(3):388-97.

15. Beck J, Bierau S, Balzer S, Andag R, Kanzow P, Schmitz J, Gaedcke J, Moerer O, Slotta JE, Walson $\mathrm{P}$, et al. Digital droplet PCR for rapid quantification of donor DNA in the circulation of transplant recipients as a potential universal biomarker of graft injury. Clin Chem. 2013;59(12):1732-41.

16. Chang CP, Chia RH, Wu TL, Tsao KC, Sun CF, Wu JT. Elevated cell-free serum DNA detected in patients with myocardial infarction. Clin Chim Acta. 2003; 327(1-2):95-101.

17. Chen $\mathrm{C}, \mathrm{Xu}$ J, Huang F. Recent players in the field of acute myocardial infarction biomarkers: circulating cell-free DNA or microRNAs? Int J Cardiol. 2013;168(3):2956-7.

18. Agbor-Enoh S, Chan JL, Singh A, Tunc I, Gorham S, Zhu J, Pirooznia M, Corcoran PC, Thomas ML, Lewis BGT, et al. Circulating cell-free DNA as a biomarker of tissue injury: assessment in a cardiac xenotransplantation model. J Heart Lung Transplant. 2018;37(8):967-75.

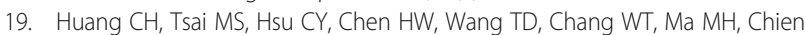
$\mathrm{KL}$, Chen SC, Chen WJ. Circulating cell-free DNA levels correlate with postresuscitation survival rates in out-of-hospital cardiac arrest patients. Resuscitation. 2012:83(2):213-8.

20. Arnalich F, Menendez M, Lagos V, Ciria E, Quesada A, Codoceo R, Vazquez JJ, Lopez-Collazo E, Montiel C. Prognostic value of cell-free plasma DNA in patients with cardiac arrest outside the hospital: an observational cohort study. Crit Care. 2010;14(2):R47.

21. Bergman $Y$, Cedar H. DNA methylation dynamics in health and disease. Nat Struct Mol Biol. 2013;20(3):274-81.

22. Lehmann-Werman R, Neiman D, Zemmour H, Moss J, Magenheim J, VakninDembinsky A, Rubertsson S, Nellgard B, Blennow K, Zetterberg H, et al. Identification of tissue-specific cell death using methylation patterns of circulating DNA. Proc Natl Acad Sci U S A. 2016;113(13):E1826-34.

23. Sun K, Jiang P, Chan KC, Wong J, Cheng YK, Liang RH, Chan WK, Ma ES, Chan $\mathrm{SL}$, Cheng SH, et al. Plasma DNA tissue mapping by genome-wide methylation sequencing for noninvasive prenatal, cancer, and transplantation assessments. Proc Natl Acad Sci U S A. 2015;112(40):E5503-12.

24. Guo S, Diep D, Plongthongkum N, Fung HL, Zhang K, Zhang K. Identification of methylation haplotype blocks aids in deconvolution of heterogeneous tissue samples and tumor tissue-of-origin mapping from plasma DNA. Nat Genet. 2017:49(4):635-42.

25. Zemmour H, Planer D, Magenheim J, Moss J, Neiman D, Gilon D, Korach A, Glaser B, Shemer R, Landesberg G, et al. Non-invasive detection of human cardiomyocyte death using methylation patterns of circulating DNA. Nat Commun. 2018;9(1):1443. 
26. Moss J, Magenheim J, Neiman D, Zemmour H, Loyfer N, Korach A, Samet Y, Maoz M, Druid H, Arner P, et al. Comprehensive human cell-type methylation atlas reveals origins of circulating cell-free DNA in health and disease. Nat Commun. 2018;9(1):5068.

27. Beffagna G, Sammarco A, Bedin C, Romualdi C, Mainenti M, Mollo A, Cavicchioli L, Ferro S, Trez D, De Maria R, et al. Circulating cell-free DNA in dogs with mammary tumors: short and long fragments and integrity index. PLoS One. 2017;12(1):e0169454.

\section{Publisher's Note}

Springer Nature remains neutral with regard to jurisdictional claims in published maps and institutional affiliations.

Ready to submit your research? Choose BMC and benefit from:

- fast, convenient online submission

- thorough peer review by experienced researchers in your field

- rapid publication on acceptance

- support for research data, including large and complex data types

- gold Open Access which fosters wider collaboration and increased citations

- maximum visibility for your research: over $100 \mathrm{M}$ website views per year

At $\mathrm{BMC}$, research is always in progress.

Learn more biomedcentral.com/submissions 